\title{
Exploring Consumer Motivation at Small-Scale Ski Resorts
}

\author{
Amanda Jacek ${ }^{1}$, Jimmy Smith ${ }^{2 *}$, Lindsey Elliott ${ }^{3}$, Karen Rickel ${ }^{4}$, Patti Millar ${ }^{5}$ \\ ${ }^{1}$ Niagara University \\ ${ }^{2}$ Associate Professor, Sport and Physical Education, Gonzaga University \\ ${ }^{3,4}$ Gonzaga University \\ ${ }^{5}$ University of Windsor
}

*Corresponding Author: Jimmy Smith, Lecturer, Associate Professor, Sport and Physical Education, Gonzaga University

\begin{abstract}
Sport tourism is a dynamic and rapidly growing industry that has skyrocketed to over $\$ 45$ billion. Scholars suggest that tourism should be studied from a psychological perspective to determine what motivates sport tourists to travel to specific destinations and what motivates them to return. Research on sport tourist motivation is plentiful, examining the behavior and intentions of both active and passive sport tourists. Tourists that visit a ski resort fall into both active and passive categories and possess a range of motivations. Most of the research that has been done on ski tourist motivation has focused on large-scale ski resorts.
\end{abstract}

The current research fills a gap in the existing literature by studying the motivation of ski tourists at a smallscale ski resort. Through a case study model, this research set out to understand the motivational factors and conditions of small-scale ski resorts. The results of this study will equip resort managers to provide an improved resort experience and develop targeted marketing strategies. This will also benefit ski tourists and build guest loyalty.

\section{INTRODUCTION}

Sport tourism has seen tremendous growth in North America in recent years. The Canadian Sport Tourism Alliance (CSTA) saw a 15\% increase in sport tourism (domestically and internationally) from 2013 ( $\$ 5.8$ billion) to 2019 (\$6.8 billion) (Sport Tourism Canada, 2020). According to the 2017National Association of Sports Commissions ${ }^{1}$ (NASC)state of the industry report, the United States saw a $26.1 \%$ increase in spending associated with sport tourism between 2012 and 2016 totaling $\$ 10.74$ billion (NASC, 2017).Since then, sport tourism has skyrocketed to a $\$ 45.1$ billion industry as of 2019 (Sports ETA, 2020), a 400\% increase. The sport tourism industry encompasses many different typologies of sporting events and activities (cf., Standeven \& De Knop, 1999). Active sport tourism includes event-based sport tourism (e.g., softball tournament or marathon events) or nonevent-based sport tourism (e.g., golfing and fishing) (Gibson, 1998a, b; Hinch \& Higham, 2001; Kaplanidou \& Gibson, 2010). Passive sport tourism includes those traveling for spectatorship (e.g., Super Bowl or the World Cup)in addition to spectatorship travel for nostalgic reasons (e.g., Hockey Hall of Fame) (Fairley, 2003; Hinch \& Higham, 2001; Kulczycki \& Hyatt, 2013). Moreover, sectors of the sport tourism industry may be refined and specialized (Gibson, Attle, \& Yiannakis, 1998) such as adventure tourism ${ }^{2}$ that include activities such as snowboarding and skiing, or those activities that include an element of danger that will increase the excitement of the sport or physical activity (Beedie \& Hudson, 2003).

Research related to the motivations of individuals seeking out active and passive sporting activities is plentiful. From an active perspective, sport tourism motivation research has reviewed multiple facets of the industry with regard to sport related vacations based on age group (early, middle, and late adulthood) (Gibson et al., 1998; Ijspeert \& Hernanadez-Maskivker, 2020), behavior intentions of distance runners traveling to events (Shipway \& Jones, 2007; Getz \& McConnell, 2014), satisfaction

\footnotetext{
${ }^{1}$ In 2019, the NASC rebranded their name and logo to Sports ETA (Sports ETA, 2019).

2 Places such as oceans, lakes, rivers, deserts, mountains, jungle, and other non-urban areas offer potential adventure sport tourism opportunities (Beedie \& Hudson, 2003)
} 
of sport tourists at small-scale reoccurring events (Kaplanidou \& Gibson, 2010; Jeonget al., 2020), motivations and typologies of the golf tourism industry (Kim \& Ritchie, 2012; Serrano-Gómez et al., 2020), and understanding destination image for winter sport tourist and their future behaviors (Hallmann et al., 2015; He \& Luo, 2020).

From a passive or spectator sport tourism perspective, research has uncovered further understanding as to why college football fans travel with their teams (Cho et al., 2019; Gibson et al., 2002; Falls \& Natke, 2016), the behavioral intentions of tourists attending Olympic Games (Brown et al., 2016; Kaplanidou, 2006; Park et al., 2019), understanding the attachment to sport teams from a sport tourism viewpoint (Prayag et al., 2020; Smith \& Stewart, 2007), and a nostalgic view of why spectators travel to watch professional teams that have relocated (Cho et al., 2017; Kulczycki \& Hyatt, 2013).

Scholars suggest that tourism behavior should be studied from a psychological standpoint, as it requires the analysis of human motivational factors (Filep \& Laing, 2019; Gnoth, 1997; Skavronskaya et al., 2017; Vada et al., 2019). Motivation, which drives human action, is imperative to understand tourism behavior as it provides insight into why individuals travel to destinations and what motivates them to return (Bédiová\& Ryglová, 2015; Hsu, 2010; Hsu \& Huang, 2010; Tjørve, Lien, \& Flognfeldt, 2015). "Motivation and decision making of the sport tourists are determined by a special interest (Hall \& Weiler, 1992) such as a particular sport activity or practicing sports in a particular environment" (Hallmann et al., 2012, p. 147). As the sport tourism industry continues to grow, a clear shift in how individuals consume sport through participation (e.g., active or passive) is evident. Therefore, the current study's research question becomes: what motivates sport tourists to venture beyond their hometown and seek out sporting activities? Also, how do skiers' perceptions compare and contrast with those of management? While the opportunity to continue research in many of the aforementioned areas is plentiful, the current research takes aim at bridging the gap in understanding lesser-known active sport tourism motivation through research participant interaction on the day of participation. Similarly, research has provided limited attention to adventure tourism related to smaller ski resorts that may attract individuals for reasons relating to their size. As a result, little is known about the reasons individuals travel to smaller, less known ski resorts.

The current research is grounded in an understanding of Maslow's (1943) hierarchy of needs as many build their motivation to travel in an effort to reach the pinnacle of Maslow's model of selfactualization. The purpose of this paper is to address the existing gap in sport tourism literature and provide insight into the unique factors and motivations that draw individuals to small-scale ski resorts as much of the current ski-related tourism motivation research focuses on large resorts (c.f. Alexandris et al., 2009; Moreno-Gené et al.,2018). The current research will add to the existing literature by examining motivational factors and conditions of small ski resorts. There are many benefits of this study. First, managers of ski resorts will better understand why skiers visit their resort which will allow them to provide an improved experience to build guest loyalty and keep them coming back. Second, marketing to ski tourists based on these motivations may become more targeted. Finally, ski tourists who visit this ski resort will benefit from an enhanced resort experience due to targeted marketing and resort offerings implemented by management as a result of this study.

\section{LiTERATURE REVIEW}

Sport tourism, as discussed broadly can include numerous categories and can range in motivational explanations (Gibson, 1998a, 1998b). Existing research targets those that already participate in skirelated tourism and focuses on their reasons for travel, as well as their motives to travel to a specific ski resort. The motivation process can be broken down to discover the driving factors behind these decisions (Gnoth, 1997). Motivation is analyzed not only to determine the reasoning behind why individuals travel to a specific destination but how to gain the repeat customer. Repeat business is vital to the success of an operation.

\subsection{Motivation}

Motivation can be classified as one of the many reasons why people act the way that they do and is in part impacted by cognition (Braver et al., 2014). Motivation is dependent on context; it can vary from situation to situation where human character traits respond to stimuli and individual sets of beliefs (Deci \& Ryan, 2000). Motives often imply a specific course to a target, yet only motivation can 
actually include the target and its objectives, leading to a specific behavior based on an individual's motivation (Gnoth, 1997). While motivation can be applied to numerous scenarios within the tourism industry, understanding motivation and what inspires travelers to visit a destination provides managers with the tools to create a more valuable customer experience, a more memorable stay, and hopefully, repeat business (Hsu \& Huang, 2010).

An individual's level of ability or skill plays a large part in the destination or activity that each traveler will choose (Weiner, 1985).One's intrinsic motivation guides their decision in choosing where and how to participate in physical activity. Intrinsic factors include perception of fun, personal challenge, and personal affiliation (Lulescu, 2020). In the skiing context, for example, it is unlikely that a traveler will choose a destination with primarily difficult slopes if they do not feel as though they could skillfully and enjoyably ski down enough of the slopes. The skier's self-efficacy or "their belief in the capability to execute the courses of action required to produce given attainments", (Bandura, 1997, p.3) such as navigate the specific ski runs with agility and lack of numerous crashes, influences the skier's travel choice. The ability or lack of ability can either positively or negatively impact experience. If a traveler knows that he or she will not succeed in a specific location, they will likely have low self-efficacy and a lack of motivation by the challenge and will, instead travel to a destination or choose an activity in which they are sure they will succeed based on their ability. As individuals increase their mastery and log these as past performances, (one of the sources of selfefficacy) their motivation to attempt new and possibly more challenging experiences, positively influences their agency and personal control (Lox, et al, 2020). One's perceived self-efficacy is consistently a strong predictor of athletic performance (Cox, 2011) and they work harder and persist in the activity longer, thus achieving at advanced levels (Zinsser, Bunker, \&Williams, 2010) and potential to travel to try new challenges.

Possessing insight to the motivation of tourists is vital to the travel industry as it provides key information that can equip travel resorts to provide a range of activities that appeal to varying levels of ability, thereby ensuring resorts' continued success.

\subsection{Maslow's Motivation}

In Maslow's hierarchy of needs, Maslow describes the hierarchy of needs in the form of pyramid with five levels. The first two levels encompass basic physiological needs imperative to survival such as food and water. The second level describes needs of safety and the feeling of being secure. Level three is related to psychological needs of belongingness and love related to intimate relationships and friendship. Next is the need of esteem and the feeling of prestige and accomplishment. The fifth and final stage at the top of Maslow's hierarchy of needs is self-actualization wherein individuals achieve their full potential throughout many facets of their life including their personal life, professional life, and other creative endeavors (Maslow, 1943; 1954; 1962; 1970; 1987).People tend to target higher level needs, such as self-actualization, once their lower needs have been met (Maslow, 1943).

With regard to the broad context of tourism, self-actualization at the top level of the hierarchy tends to motivate travel actions most often. Motivation in the travel industry is largely impacted by a holiday. Pearce (1982) suggested that people are attracted to holiday destinations because they are seeking the possibility of achieving self-actualization. Travelers will often use days off or holiday time to travel. The motivation to travel would not have been created if it were not for the extrinsic factor of having time off (Gnoth, 1997). A push-pull motivational framework identified by Dann (1977) claimed that the push factor are aspects in individuals' lives that lead to taking a vacation beyond the natural agenda of daily life. The push represents the needs and wants of travelers such as rest and relaxation. The pull aspectsare related to the decision to select one destination over another based on features such as sunshine, sports facilities, or affordability of travel (Klenosky, 2002). Free time, or the vacation, is becoming increasingly related to the concept of self-actualization and individual's destressing themselves from their daily aggravations (Chen et al.,2016). The idea of reaching selfactualization is a large motivational factor (Maslow, 1954) simply because individuals are looking to find themselves and reach their full potential.

Maslow's theory of motivation as it relates to self-actualization is useful in travel research as it provides an explanation for why individuals travel and the possibilities for why they have chosen a specific destination. All the categories in the level of self-actualization can be broken into two conceptual frameworks. Deci and Ryan (2002) defined these two frameworks toward the motivation 
of each traveler as the Travel Career Ladder (TCL) and the Travel Career Pattern (TCP), both of which are based on Maslow's hierarchy. Simply put, the TCL measures how well-traveled a person is. The more traveling one does, the higher they move up the ladder. The TCL is based on the "conceptualization of psychological maturation towards a self-actualization goal" (Deci \&Ryan, 2002,p. 16). In this framework, the underlying core idea suggests that individuals' travel needs change over the course of their lifetime because of their previous travel experiences. Travelers begin to know exactly what they are looking for when traveling and move their way quickly up the hierarchy of needs, requiring and seeking fulfillment of the higher-level needs. This framework additionally suggests that experienced travelers will be very predictable and tend to travel within a specific pattern (Deci \& Ryan, 2002; Lee \& Pearce, 2002). The TCP, while similar to TCL, suggests that the higher the traveler is on the TCL, the more likely they will be looking for something different and more original. TCP lays out the motivating factors of travelers at each stage of their travel career. This framework further classifies individuals into two clusters: the first being those that are more seasoned travelers who seek novelty, kinship, and the opportunity to escape/relax; and the second being those that are newer to travel, have less expectations, and are motivated by a variety of factors such as nostalgia, stimulation, isolation, and social status (Lee \& Pearce, 2002).

\subsection{Sport Tourism}

Sport tourism is an institution where people of all economic backgrounds can seek association with one another and come together around a common interest in sport travel (Keller, 2001). Williams and Fidgeon (2000) suggest that sport and tourism are generally studied as two separate entities. However, to explicitly understand what sport tourism is and what drives tourists, sport and tourism must be studied together (Gibson, 1998a, b). In the past, there has not been a clear definition of sport tourism, as definitions are adjusted depending on the context. This has made it challenging to properly categorize scholarly articles and research on the subject (Hinch \& Higham, 2001).Toward addressing this difficulty, Hinch \& Higham (2011) proposed a definition of sport tourism "as sport-based travel away from the home environment for a limited time, where sport is characterized by a unique set of rules, competition related to physical prowess and a playful nature" (p. 20).

The push for globalization (Bernstein, 2000) and democratization (Standeven \& DeKnop, 1999) has had significant effects on the way sport is consumed and the development of sport tourism. Hinch and Higham (2011) suggest that there are two main categories of sport tourism: travel to participate and travel to spectate. Countries with different political and religious beliefs have been able to put them aside to come together to celebrate the similarities in sport interests (Higham \& Hinch, 2004).

The demographics of the common sport tourist have expanded with the rise of health and fitness in the western world (Glyptis, 1989). Preceding Hinch and Higham (2011), Gibson (1998) noted that a category was added to sport tourism to make categorizing travelers more specific. This category includes those that are traveling for nostalgic reasons to locations such as sports halls of fames, famous stadiums, sports museums, and sport-based cruises. Gibson(1998)noted that there is a new form of tourism on the rise which includes hard and soft travelers. 'Hard' and 'soft' tourism have become notable with the rise in extreme sports. 'Hard' tourism is travel done with the intent of competition and 'soft' tourism is associated around holidays or participation for only recreational purposes (Finn, 2012).

As global safety becomes a concern around the world, the travel and tourism industry must discover ways to be innovative in how they attract consumers, as well as how they are going to ensure their safety (Floyd et al., 2001). Climate is an important factor to region and seasonality because it not only dictates which sports are performed during which season, but it plays an important role in overcoming the challenges that sport complexes face when dealing with seasonal change. With recent evidence supporting increases in interest, both the sport and tourism industries stand among the largest and fastest growing in the global economy (Higham \& Hinch, 2000, IBIS World, 2021). Sport Tourism Destinations, such as ski resorts, have found a way to make use of all seasons (e.g., spring and summer hiking and biking tours) by creating participation opportunities in new indoor and outdoor facilities, thereby increasing sport tourism year-round and changing sport travel patterns (Higham \& Hinch, 2002). As indicated, climate can impact the time of year individuals' travel; however now that year-round sport facilities have been added, prime season can last all year long. 


\subsection{Ski Resort Motivation}

Links between motivation and destination choice have been found to influence one another (Pearce, 1996). Previous research has shown that an individual's reasoning to travel and select a specific destination can change from the point of decision making up until the guest returns home. This suggests that an individual may be motivated to visit a destination for one reason and may leave with a different motivation to return. Gengler and Klenosky (1999) suggest that the position of the ski resort (meaning location and surroundings) can additionally motivate customers to visit. It was found that the factors that contribute most to customer attraction and customer loyalty in relation to the amenities and surrounding area include accommodation, restaurants and social life, resort facilities and services, quality of slopes, quantity of slopes, proximity, access and price (Gengler \& Klenosky, 1999).It is specifically noted that when in the process of making a decision on a ski resort destination, accommodations should be of high quality, affordable, and provide a variety of options.

Hudson et al. (2004) analyzed the competitive nature of current ski resorts and the reasons behind their consumer's travel. They found that many ski resorts diversified their services as the "number of skiers and snowboarders has been falling in the United States since the early 1990s" (Hudson et al., 2004, p. 508, IBIS World, 2020). With falling participation rates, winter resorts have decided that they must offer a wide range of winter off- and on-slope activities to generate interest. For example, many resorts have begun to offer ice-skating, sledding, and tubing (Hudson et al., 2004).

A host of studies have examined ski resort motivation by ski tourist segmentation. Ridding ton et al. (2000) studied Scottish ski tourists and found that day trippers were motivated by snow accumulation, cost, and journey length while overnighters' ski resort choice was driven by accommodations (e.g., hotels, restaurants, shopping). Konu et al. (2011) identified six customer segments in their study of Finnish ski resort customers while Hall et al. (2017) studied an Australian ski resort and identified five segments. Both studies have implications for managers in that strategies can be developed "to enhance marketing for segment-specific attributes that could assist in differentiating the ski tourism offering, improve competitiveness, and create a destination image based on the tangible and intangible attributes that motivate each segment" (Hall et al., 2017, pp. 774-775).

Studies of ski tourist by segmentation have also found that different groups possess different sensitivities to price and destination choice. Tjørve et al. (2015) found there were differences in motivation between first time visitors and repeat visitors of Norwegian ski resorts. Repeat visitors tend to be less price sensitive and typically prefer self-catering accommodation (Tjørve et al., 2015). College skiers and snowboarders in Korea were also found to be less concerned with price and more motivated by the snow quality, average lift wait time, and travel time to the ski resort (Won \& Hwang, 2009).Many of these studies are discussed in Bédiová's and Ryglová's 2015 work which provides a summary of scientific approaches to the study of destination choice, satisfaction, and loyalty of consumers in the ski tourism industry, the purpose of which is to serve as the foundation for further studies in this area.

\section{METHODS}

Many research studies, such as the ones discussed above, are conducted using large or more wellknown facilities, without giving much notice to smaller less popular facilities (Mansfield \& Pizam, 1999). For the purposes of size classification, the National Ski Areas Association (NSAA) categorizes ski resorts using an industry statistic called vertical transportation feet per hour $(\mathrm{vtf} / \mathrm{h})^{3}$, a metric related to the carrying capacity of a ski area. According to this metric, the NSAA (2021) has determined that of the 470 ski resorts in the United States, 266 ski areas are small, 81 are medium, 64 are large, and 59 are extra-large ski areas. In correspondence with NSAA and based on the parameters of the ski resort involved in this study, a small-scale ski resort was designated. The current research aims to bridge a gap in the research to better understand the motivations that drive travelers and consumers to visit small ski resorts. This research compares and contrasts the views that management have about their visitors with the views the visitors have of themselves, and how it relates to previous research on travel motivations. To accomplish this, the current research utilized a case study approach.

\footnotetext{
${ }^{3}$ (A. Isaac, personal communication, March 8, 2021)
} 
The importance of case study research is to offer contributions to the literature of lesser-known topics or settings focusing on a specific individual, group, or association (Yin, 2011). While there is an abundance of large scale ski resort literature, research is limited related to small scale ski resorts especially in the North American setting. The essence of case study research is to offer a comprehensive review of a specific example of phenomena. Therefore, the intent of case study research is not to offer generalizability of the topic (in this case small scale ski resorts), but to set the stage for continued investigation (Abercrombie, Hill, \&Turner, 1984; Flyvbjerg, 2006, Yin, 2011).

Limitations to previous small scale ski resort research guide the necessity of case study research. Miles and Huberman (1994) suggest that, "a phenomenon of some sort occurring in a bounded context. The case is, "in effect, your unit of analysis" (p. 25).Given these parameters, it was determined that the unit of analysis for the current research was one small ski resort in the United States.

\subsection{Case: Northeast Small Ski Resort (NESSR)}

The ski resort in question is located in the Northeast ${ }^{4}$ region of the United States. For confidentiality purposes, a pseudonym is used for the name of the small ski resort where research was conducted: Northeast Small Ski Resort (NESSR). NESSR is classified by NSSA as a small ski resort (vtf/h) located in the Southeast corner of the State. The selection of resort was based on its wide variety of service options, as well as the region of travelers that it could potentially target. The small town of Southville (a pseudonym) contains many locally owned restaurants, bars, and shops that are largely funded by the travelers coming to NESSR, according to local economic data. NESSR resort has more than 75 slopes ranging in difficulty level from Green Circle (easy) to Double Black Diamond (expert only) and includes a terrain park. To service the more than 75 slopes, there are 13 full-service lifts. The average snowfall for the resort is 180 inches with a $95 \%$ coverage ability of snow (including their 611 snow guns), making it an excellent place to visit during the winter months.

\subsection{Participants and Procedures}

Participants were over the age of 18 and all had skied or snowboarded for a minimum of five years. All participants traveled with a minimum of one additional person in their vehicle and multiple individuals who were interviewed for the current research traveled together. Permission from the general manager of NESSR was granted to conduct interviews on the premises. Data was collected on a Saturday morning at 9 o'clock am, as it was reported by the management team at NESSR that Saturdays bring in the highest number of guests. Mornings were identified as an ideal data collection time because travelers would have either come the night before and stayed over, or they would have woken up early and driven in to take full advantage of the entire day.

Interviews were conducted in the main ski lodge. Both male and female skiers and snowboarders of all skill levels were interviewed. The interview targeted participants' motivation for choice of destination. Information such as distance traveled and number of times they have visited the resort was also collected. The interviews were conducted in an informal setting (being in a non-private area) by a single interviewer.

In addition to interviewing skiers and snowboarders, similar questions (modified only slightly to fit the study participant) were asked to a member of the NESSR management team to ascertain their thoughts on why their customers come to their ski resort. The interview with a member of the NESSR management team was considered important to gain their perspective of NESSR consumer motivation and actual consumer motivation. This was done to compare and contrast the differences between the skiers' perceptions and those of the management.

\subsection{Data Analysis}

The data collected were categorized into main themes based on the participant responses (Gibbs, 2007).Saldaña (2013) notes that "thematic analysis or the search for themes in the data is a strategic choice as part of the research design that includes the primary questions, goals, conceptual

\footnotetext{
${ }^{4}$ The Northeast region of the United States was determined by the United States Census Bureau regional office map (US Census, 2020).
} 
framework, and literature review" (p.200). Each theme was chosen by analyzing responses from participants relating to questions surrounding positive feedback about the resort, its amenities, and environmental conditions. Defining terms were selected to provide a simple explanation of the more specific data included. Themes were also developed based on the data categorizing negative responses about the resort, its amenities, and environmental factors.

\section{Results}

Data were collected from 18 skiers and snowboarders on a Saturday morning during the height of the ski season. The results were divided into two primary categories: descriptive statistics (e.g., the distance traveled to the resort) and narrative responses that describe the motivations of the participants for visiting NESSR. The findings of this study demonstrate the differences in distance traveled from guest to guest, the number of times guests have visited the resort, the quality of the resort that most encourages guests to visit, guests' main purpose for coming to NESSR, what participants found most disappointing about the resort, and what participants enjoyed most throughout their trips. The findings of this study are beneficial to the ski resorts themselves, as they will provide the resort management with a better understanding of elements that drive consumers to visit and return to destinations similar to NESSR. In turn, the participants will also benefit from an improved resort experience as a result of targeted marketing and resort offerings implemented by management as a result of this study.

\subsection{Distance Traveled}

The distance that the participants traveled to NESSR varied. Table 1 represents the size of city participants traveled from, the number of participants from each location, and the travel timeto arrive at NESSR.

Table1. Traveling to NESSR ${ }^{5}(n=18)$

\begin{tabular}{|c|c|c|}
\hline $\begin{array}{c}\text { Size of city/town traveled from } \\
\text { the nearest } 1000\end{array}$ & $\begin{array}{c}\text { Number of participants from each } \\
\text { location }\end{array}$ & $\begin{array}{c}\text { Travel time to NESSR to } \\
\text { nearest 30 minutes }\end{array}$ \\
\hline 2.9 million & 1 & $21 / 2$ hours \\
\hline 383,000 & 1 & 3 hours \\
\hline 256,000 & 7 & 1 hour \\
\hline 206,000 & 3 & 2 hours \\
\hline 38,000 & 4 & $21 / 2$ hours \\
\hline 8,000 & 2 & $<20$ minutes \\
\hline
\end{tabular}

Table 2 represents the number of visits participants made to NESSR. There were three participants that indicated they had traveled to NESSR more than 900 times in their life. Linking this to Table 1, the individuals that visited NESSR more than 900 times were within one-hour of the resort. These respondents were NESSR season pass holders (more than five years) that traveled to the resort multiple times per week during the ski season.

Table2. Number of visits to NESSR $(n=18)$

\begin{tabular}{|c|c|}
\hline Number of visits to NESSR & Number of participants that visited NESSR \\
\hline $1-20$ & 6 \\
\hline $21-40$ & 4 \\
\hline $41-60$ & 1 \\
\hline $61-80$ & 0 \\
\hline $81-100$ & 0 \\
\hline $101+$ & 7 \\
\hline
\end{tabular}

\subsection{Motivations for Choosing NESSR}

After analyzing participant responses, it was discovered that there were many positive comments relating to the numerous motivations for traveling to the resort. Responses encompassed in this category as mentioned by participants include the quality of NESSR that has most encouraged guests to travel, guests' main purpose for visiting NESSR, and the most favored aspect of NESSR. There were two primary categorized themes that held sub-themes related to individual motivation. Responses in Table 3 represent resort-related features that impact motivation with three sub-themes or

${ }^{6}$ Size of city was collected from United States Census Bureau (U.S. Census, 2020). 
individual level aspects. The responses represented in Table 4 are related to motivation based on individual features with four sub-themes. Sub-theme determination was developed based on five or more respondents noting the motivation for traveling to NESSR.

Table3. Summary of motivations for choosing NESSR (Resort related)

\begin{tabular}{|l|l|l|}
\hline $\begin{array}{l}\text { Primary Theme } \\
\text { Resort Related }\end{array}$ & Description & Example \\
\hline Slopes & $\begin{array}{l}\text { Refers to the quality and number of the } \\
\text { slopes themselves, as well as their } \\
\text { condition. }\end{array}$ & $\begin{array}{l}\text { Fast lifts, variety of slope difficulty } \\
\text { levels. }\end{array}$ \\
\hline Location & $\begin{array}{l}\text { Describes where the resort sits within } \\
\text { Southville, including the night life as } \\
\text { well as the appropriate distance } \\
\text { between major cities. }\end{array}$ & $\begin{array}{l}\text { Located in Southville and its night life, } \\
\text { as well as the wooded areas on the } \\
\text { slopes, hospitality of the region brings } \\
\text { a sense of community, good distance } \\
\text { between the neighboring state(s). }\end{array}$ \\
\hline Amenities/Facilities & $\begin{array}{l}\text { Offers an explanation of the types of } \\
\text { services and features that customers } \\
\text { enjoy and expect. }\end{array}$ & $\begin{array}{l}\text { Number of lodges, atmosphere of } \\
\text { lodges, cleanliness, ability to purchase } \\
\text { alcohol. }\end{array}$ \\
\hline
\end{tabular}

Table4. Summary of motivations for choosing NESSR (Individual related)

\begin{tabular}{|l|l|l|}
\hline $\begin{array}{l}\text { Primary Theme } \\
\text { Individual Related }\end{array}$ & Description & Example \\
\hline $\begin{array}{l}\text { Default Option } \\
\text { (individual level) }\end{array}$ & $\begin{array}{l}\text { NESSR is the best resort in the } \\
\text { participants' area. }\end{array}$ & $\begin{array}{l}\text { Participants may have chosen the resort } \\
\text { simply because they do not have } \\
\text { anywhere else to go in their area. }\end{array}$ \\
\hline $\begin{array}{l}\text { Social } \\
\text { (individual level) }\end{array}$ & $\begin{array}{l}\text { Refers to the act of being with others as } \\
\text { well as enjoyment. }\end{array}$ & $\begin{array}{l}\text { Socialization, relaxation, enjoyment, } \\
\text { and the ability to get away from home. }\end{array}$ \\
\hline $\begin{array}{l}\text { Nostalgia } \\
\text { (individual level) }\end{array}$ & Describes the feeling of belonging. & $\begin{array}{l}\text { Family bonding and enjoying the view } \\
\text { around them. }\end{array}$ \\
\hline $\begin{array}{l}\text { Personal Betterment } \\
\text { (individual level) }\end{array}$ & $\begin{array}{l}\text { Refers to the idea that visiting the } \\
\text { mountain makes the individual a better } \\
\text { person and skier/snowboarder. }\end{array}$ & $\begin{array}{l}\text { Being outside breathing the fresh air, } \\
\text { refining their skill, and getting } \\
\text { exercise. }\end{array}$ \\
\hline
\end{tabular}

First, participants felt that factors relating to the slopes and the mountain itself were important when choosing to attend NESSR. Many participants spoke to the fact that there is a large number of slopes for the size of the mountain, as well as the ability of the resort to keep the slopes maintained. Slope maintenance includes keeping the slopes well-groomed with plenty of snow and keeping unsafe objects out of the main passageways (e.g., rocks). In addition to NESSR's plentiful slopes, they range in difficulty level providing satisfaction at all skill levels. Slope difficulty levels range from Green Circle, which are the easiest, to Double Black Diamond which require an expert level of skill. The lifts that are provided are not only quick, but they are also accessible from all sides and slopes on the mountain.

Second, another common theme that was evident in the data was that the resort was built in an ideal location. NESSR is in the heart of Southville, a small ski town that has many restaurants, bars, and shops for the guests to visit during their down time. Not only is the resort located within ideal surroundings, but it is geographically located, as Table 1 denotes, in between many major metropolitan areas. Participants chose to come to NESSR because it is a prime distance from home; for some, it is not too far and so can be a day trip, but for those that need to stay a night or two, amenities are available for such a trip. Participants liked that the slopes themselves had wooded areas that were more secluded than the open sections of the slopes that many people were on. In addition, some individuals suggested that the night life in Southville allowed them to ski during the day and go out for some fun at night. Although many individuals answered with specific examples, a majority of participants mentioned that they come to NESSR because it is the best that they can get. Those making the drive to the resort feel as though NESSR is their only option for good skiing within a reasonable driving distance. For many, their only reasoning for choosing the resort was that it was the best resort in the participant's area that they could easily get to, either as a day trip or a weekend trip.

Amenities, and the facility in general, were also proven to be rather important to participants. NESSR keeps all of their facilities updated and clean. The atmospheres of the lodges are warm and inviting, 
not to mention the fact that there are lodges located within the mountain making it easy to stop and relax, chat with friends, or get something to eat. Many guests also like the idea that alcohol can be purchased at more than one location, especially because many times they are skiing with friends and would like to catch up over a drink in the lodge.

Many chose NESSR for the act of socializing with friends and being around other people. Included in this theme is the idea that the resort provides a way for individuals to relax and get away from their every-day life for a little while. Many find skiing at NESSR to be relaxing and enjoyable, leading everyone to become a repeat customer. Nostalgia-based travel also shows itself as a main theme for motivational factors. All the participants in this study were repeat customers, and they explained that NESSR is a place where they can bond with their family, spouses, and children. A few individuals also mentioned that the view of the surrounding area is beautiful, both from the top of the hill and from the bottom.

Additionally, participants mentioned that personal betterment motivated them to travel to NESSR. Interviewees claimed that they were seeking the opportunity to better refine their skills as well as the ability to socialize with other individuals that were doing the same things at the resort. Included in this was the ability for participants to be outside getting fresh air and more exercise.

An important theme that presented itself was the overall experience that guests received. Included in this are the memories and relationships that were made along the way. A majority of individuals said that because they had been coming for many years, they met and developed friendships with other guests that they continue to meet up with and coming to NESSR has become a common ritual for them as a way to reconnect. There was only one individual who was completely unsatisfied with their experience and said that they did not enjoy any aspect of the resort but loved skiing and did not have anywhere else to go.

Lastly, social variety within the overall experience appeared important. NESSR offers a range of programs including those for children which allows people of all ages to find something fun to do. Along these lines, it was also mentioned that because NESSR provides opportunities for all ages to have a great time, it produces a family friendly environment that many people claimed to enjoy and take part in. See table 1 for more explanation on why individuals chose NESSR.

\subsection{Unfavorable Aspects of NESSR}

Although there are many positive factors that motivate visitors to visit NESSR, a few themes were identified as relating to visitor disappointment. Many concerns regarding environmental circumstances were identified by participants that are somewhat out of the resort's control. Participants felt that occasionally the slopes were too icy, making their ride down unpleasant. One individual stated that the length of the slopes was too short. Additionally, many stated that the snow making process, while a nice option for creating snow when necessary, leaves participants with iced up goggles creating obscured vision while going down the slopes where the snow is being manufactured.

Additional themes from the participant interviews related to hospitality, business, and how the resort was managed. Hospitality included all the services that are provided by the front-line staff and those aspects that are handled by the managerial staff. Several participants noted that the staff both in the lodges and out on the slopes were unfriendly. One individual referred to the staff (who walk around in black and white striped referee outfits) as "table Nazis", which is indicative of participants" perceptions of the front-line staff. Staff unfriendliness was serious enough to cause participants to question whether they would even come back to the resort. One individual commented on an idea to enhance customer experience by providing special events such as live music in the lodge. In addition, the lines at the ski lifts were too long and although they were well-managed, the length of wait time was still frustrating.

An additional frustration involved lack of storage space for skiers' personal items and the food options provided. It was explained that the lockers once available for use had been taken away, leaving skiers without a safe place to store their belongings during the day. While many understood that they could bring their own food, participants felt that providing high quality food for purchase should be of high importance to management, yet the high cost of food did not match the food quality, described by participants as poor. 
Finally, many of the resort-run business aspects left guests with unpleasant memories. Table 5 is a summary of aspects of NESSR that were disappointing to the participants. A majority of the participants noted that the prices of lift tickets, equipment rentals, and food items had increased in price over the years, limiting the frequency of returning to the resort prior to that of being interviewed. The parking system was a large concern given that it is both limited and often far away, requiring visitors to carry all of their equipment a long way to the slopes.

Table5. Summary of Unfavorable aspects of NESSR

\begin{tabular}{|l|l|l|l|}
\hline Theme & Description & Example & $N(\%)$ \\
\hline Environmental & $\begin{array}{l}\text { Circumstances that are beyond the } \\
\text { control of the resort. }\end{array}$ & $\begin{array}{l}\text { Vertical feel of the mountain is too } \\
\text { short, sometimes icy, hard to see } \\
\text { when making snow. }\end{array}$ & $27.7 \%$ \\
\hline $\begin{array}{l}\text { Hospitality } \\
\text { (resort-related) }\end{array}$ & $\begin{array}{l}\text { The services that are provided by the } \\
\text { resort to the guests. }\end{array}$ & $\begin{array}{l}\text { Unfriendly staff, long lines at lifts, } \\
\text { no lockers, and food is horrible. }\end{array}$ & $27.7 \%$ \\
\hline $\begin{array}{l}\text { Business } \\
\text { (resort-related) }\end{array}$ & $\begin{array}{l}\text { How the resort conducts their } \\
\text { business aspects. }\end{array}$ & $\begin{array}{l}\text { Prices are getting too expensive, the } \\
\text { parking format is poor, and there is } \\
\text { not live music in the lodges. }\end{array}$ & $27.7 \%$ \\
\hline
\end{tabular}

Note. $N$ refers to the percentage of respondents that identified the respective theme.

\subsection{Resort Management Perspective}

One member of the NESSR management team was asked to respond to similar questions regarding the motivations of visitors who spend time at their resort. The difference in this interview was that the management team member was asked to respond with the answers they thought their customers would say. This individual responded that the average distance that most of their guests traveled was 115 miles, with a great majority of their guests coming from the two closest metropolitan cities. With the response to the first question in mind, the member of the management team suggested that the average length of stay is 1.5 days, taking into account those that stay for the entire weekend and those that just come for the day. It was explained that this number could be partly impacted by the distance that the guests need to travel to come to the resort. When asked what the management team thought to be their most vital asset, they responded that their friendly staff is the key to their success. The interviewee stated that you could have the most magnificent mountain, but if the staff is not kind it will drive your customers away. In response to asking the management team member the prime reason visitors choose NESSR, they said that the overall quality of the resort attracts customers. This includes the variety of trails, the number of lifts, lodging, location, and the friendly staff; all the aspects of the resort create an inviting environment.

\section{DISCUSSION}

After the data were collected and analyzed, it became clear that a large portion of the data supported previous research studies. Sport tourism, in this case, proved to have many different motivations and ranged from person to person. As Floyd et al. (2001) stated, sport tourism motivation can range in explanations. One of the key themes related to the quality of the slopes. Not only were the quality of the slopes themselves a condition of motivation, but their total number and the varying levels of difficulty also proved to be extremely important to many participants as well. In previous research, Weiner (1985) suggested the level of ability among participants will dictate a destination choice and the level of activity each traveler will choose. At NESSR, there are four different levels of difficulty to support everyone's needs, ranging from beginner to extreme. The variety of difficulty also proved very important to a majority of the participants because they commented that they liked to travel to NESSR to be together with their friends and family, who all range in age and experience level. Research supports the idea that if individuals do not feel that they will be successful if they choose a specific ski resort, they will likely not go (Weiner, 1985) as was found to be the case with the ski resort studied here. Customers enjoy the variety therefore they choose to return. One inconsistency was discovered because some guests stated that the lifts were fast, although another participant stated that they were disappointed that the lines to get onto the lifts were too long. In this instance, it would be important to note that the long lines may not relate to the speed of the lifts but rather the number of people in line.

Many of the participants expressed that their travel decisions are in line with the theories provided in the TCL which refers to their understanding of what they are looking for when choosing a destination. 
As represented in the data above, many of the participants were seasoned customers. With data ranging from 10 visits and upwards of 900 visits, the participants being seasoned customers now know exactly what they are looking for in the resort. It is possible that those traveling over 900 times have chosen to return so often due to nostalgic reasons. Nostalgia based travel simply means that an individual is returning to a destination that has happy associations. In sports, a sport destination may bring back this feeling of happiness and belonging (Gibson, 2006). Those visitors that have traveled to NESSR over 900 times are a perfect example of someone advanced in the TCL. They have likely visited other locations in the past, making them experienced travelers. The fact that they return to NESSR shows that they have determined what they like in a ski resort and have found that NESSR fulfills their needs. They also expect to meet new friends and be able to enjoy a stay on the premises. All the individuals that were interviewed fall into cluster 1 of the TCL in that they seek escape and relaxation and look for relationship. Again, participants felt that the social aspects of making new friends over the years and looking forward to making new friends every time they visit the resort were important in their choosing of ski resorts. A group of participants even stated that they now meet up at NESSR all together every chance they get.

Gengler and Klenosky (1999) also suggest that the positioning (location and surrounding area) of the resort can create additional motivation. Customer loyalty and retention can largely depend on the surrounding area and amenities, accommodation, restaurants, and the social life. In this case study, the surrounding area of Southville was mentioned as a response by many participants. Participants liked the night life that is within walking distance as well as the number of restaurants and accommodations available to them. Separate from the motivational factors suggested by Gengler and Klenosky (1999), it was also found that a large number of the participants liked the location because of its easy access from their home. Many participants made their trip into a day trip and NESSR's central location allowed them to do so.

Surprisingly, there were discrepancies between the responses from the member of the management team and their customers. One of the largest discrepancies was regarding the friendly staff. In no part of the questioning process could friendly staff be included in any of the themes regarding motivations to choose NESSR. Instead, it was mentioned as a response in the hospitality theme regarding unfavorable aspects of NESSR. One participant stated that they found some of the staff, in particular those that check the tables, to be very rude and were adamant about the fact that if there was anywhere closer to their home, they would be going there instead. In addition, the management staff also mentioned that a large majority of their customers come from the two largest cities in the surrounding areas, traveling an average of 115 miles. The staff neglected to report that individuals also come from a third nearby metropolis, and more people came from an urban center in a neighboring state than from a larger city in another neighboring state. The different responses are very important because it confirms that there is a gap between the information that the resort perceives about their customers and the information that the customers are willing to provide in personal interviews. This should be a concern for the resort because it shows flaws in the way they obtain their customer information and could assist in revisiting and updating their marketing and customer retention models. See Table 6 for a summary of conflicting responses from the NESSR staff and the participants of the case study.

Table6. Summary of differences in responses between NESSR staff and participants

\begin{tabular}{|l|l|l|}
\hline Theme & Description & Example \\
\hline Friendly Staff & $\begin{array}{l}\text { Management thought their friendly } \\
\text { staff was the prime reason for } \\
\text { customers to choose NESSR. }\end{array}$ & $\begin{array}{l}\text { Interviewees thought staff to be rudeand } \\
\text { said that it gave them reason to consider } \\
\text { not returning to the resort. }\end{array}$ \\
\hline Guest City of Origin & $\begin{array}{l}\text { Management thought most of their } \\
\text { guests came from City A and City B. }\end{array}$ & $\begin{array}{l}\text { Interviewees states that in addition to } \\
\text { City A and City B, visitors came from } \\
\text { City C, City D, and City E. }\end{array}$ \\
\hline
\end{tabular}

All of the data that was collected and analyzed in this case study is extremely important in furthering sport tourism studies, especially in ski tourism because it has targeted those that are traveling from many different distances, as well as providing a range of motivational explanations. This case study provides an understanding for the motivations that small-scale ski resort travelers share. There is a large breach in the number of studies done regarding large verses small ski resorts.

This case study is supported by the same motivational information that the large-scale ski resorts report. This is a start to proving that small-scale ski resorts, ones that are not as well known, can still 
produce reputable and useful data. Mansfield and Pizam (1999) note that at large ski resorts, customers expect to be able to challenge themselves through the use of multiple difficulty level slopes. It is also mentioned that guests look to meet new people while they are at the resort. Both of these important details were found throughout this case study and prove that small-scale ski resorts (especially this one because it is the only in its area) should market themselves competitively with the larger resorts.

\subsection{Limitations and Future Recommendations}

Although relevant research was gathered, future studies may want to conduct surveys over a duration of more than one ski season because the weather was not conducive to visiting the resort for many days. This would include weekdays and different times of the day on the weekends. It is possible that interviewing on weekdays could allow for a wider array of answers. In addition, having open-ended questions made it difficult to categorize responses into themes.

For future studies, it may be helpful to frame questions so that one-word answers would be sufficient. Taking a quantitative approach would allow an examination of relationships between factors like the number of times visited, distance traveled, and a participant's overall satisfaction with the resort. It would also be helpful to conduct future research at multiple small-scale ski resorts, as it would allow for a better comparison of data, and trends in motivation could be examined and analyzed. This would also provide for a larger sample size and could possibly target individuals from different cities.

Finally, diving deeper into intrinsic and extrinsic motivation of ski tourists would be an area for further research. Intrinsic and extrinsic motivation create and depict a sense of energy, direction, and persistence which act as an activation to motivational intentions. Deci and Ryan (2002) conclude that motivational actions are created by one's value of an activity (internal) or by a strong coercion (external). The ski tourists interviewed in this research responded to questions about motivation with answers that demonstrated they were motivated by both intrinsic (e.g., to become better skiers) and extrinsic (e.g., the quality of the slopes, the nightlife in Southville) factors provided by NESSR. Further studies could examine these varied motivations in more depth.

\section{CONCLUSiON}

This case study strived to fill a gap in sport tourism research. Small-scale ski resorts have been left out of the discussion when conducting studies on customer motivation factors. Interestingly, the findings presented here support much of what previous studies have shown in relation to large-scale ski resorts. Guests were found to not generally travel more than 5 hours to visit NESSR, but they did prove to be loyal based on the number of times they chose to visit the resort. It was found that $22.2 \%$ of participants had traveled to NESSR over 900 times. These individuals have found something extraordinarily appealing in NESSR and their motives for choosing their destination have clearly been met time and time again. Additionally, 44.4\% (almost half) of participants determined that the quality of NESSR's slopes and the good condition in which they are keptis very important to them. It is also notable that $88.8 \%$ of participants responded that they have chosen NESSR for its social potential; the guests enjoy their ability to meet new people and relax. Because so many have responded with this motivation, it is something that would benefit NESSR for the management to prioritize and continue to develop.

A determinant that should be noted by NESSR management is a common theme among participants of unfriendly staff. Unfriendly staff was mentioned as being an unfavorable aspect of visiting NESSR, a sentiment that was disconnected to NESSR's own view of the level of customer service their staff provides. Feeling as though their friendly staff was one of their most vital assets, NESSR may want to reconsider reevaluating their customer service given that participants repeatedly voiced their concerns about staff unfriendliness. These results echo the findings of several studies on the effect of service quality on customer loyalty in ski tourism (Alexandris et al., 2006; Hudson \& Shephard, 1998; Kyle et al., 2010). While the customer satisfaction with their overall experience at a ski resort includes natural factors (weather, snow, etc.) that can be out of management's control, "fostering a culture among service personnel that is supportive of customer experiences, while challenging, represents a realizable goal.” (Kyle et al., 2010, p. 10).

Maslow's hierarchy and the TCL are relevant to the reasons why skiers travel and their choice of destinations. Many of the guests commented that they enjoy coming to NESSR for personal betterment as a skier and the opportunity to be in the fresh air with a wonderful view. Their internal 
ambition is driving them to achieve self-actualization and they are flooded with numerous external motives that could at times create an additional list of travel and destination choice objectives (Deci \& Ryan, 2000).However, NESSR has enough positive qualities that draw their guests back repeatedly to enjoy the ski resort.

This research has shown that small-scale ski resorts have attributes that are capable of providing ski tourists with a fulfilling ski resort experience. Understanding the motivation of their ski tourists allows management to provide an improved experience which will build guest loyalty. Furthermore, it enables management to develop targeted marketing strategies that effectively retain loyal customers and expand their customer base. Finally, as management improves the resort experience as a result of these findings, resort guests benefit from an improved resort experience which will keep them coming back.

\section{REFERENCES}

[1] Alexandris, K., Kouthouris, C., Funk, D., \& Giovani, C. (2009). Segmenting winter sport tourists by motivation: The case of recreational skiers. Journal of Hospitality Marketing \& Management, 18(5), 480499. doi:https://doi.org/10.1080/19368620902950048

[2] Alexandris, K., Kouthouris, C., \& Meligdis, A. (2006). Increasing customers' loyalty in a skiing resort: The contribution of place attachment and service quality. International Journal of Contemporary Hospitality Management, 18(5), 414-425. doi:10.1108/09596110610673547

[3] Abercrombie, N., Hill, S., and Turner, B. S. (1984).Dictionary of sociology. Harmondsworth: Penguin.

[4] Bandura, A. (1997). Self-efficacy:The exercise of control.W.H.Freeman.

[5] Bédiová, M., \& Ryglová, K. (2015). The main factors influencing the destination choice, satisfaction and the loyalty of ski resorts customers in the context of different research approaches. Acta Universitatis Agriculturae Et Silviculturae Mendelianae Brunensis,63(2), 499-505. doi:10.11118/actaun201563020499

[6] Beedie, P., \& Hudson, S. (2003). Emergence of mountain-based adventure tourism. Annals of Tourism Research, 30(3), 625-643.

[7] Bernstein, A. (2000). "Things you can see from there you can't see from here". Journal of Sport and Social Issues, 24(4), 351-369. doi:10.1177/0193723500244004

[8] Braver, T. S., Krug, M. K., Chiew, K. S., Kool, W., Westbrook, J. A., Clement, N. J., ... \& Somerville, L. H. (2014). Mechanisms of motivation-cognition interaction: Challenges and opportunities. Cognitive, Affective, \& Behavioral Neuroscience, 14(2), 443-472.

[9] Brown, G., Smith, A., \& Assaker, G. (2016). Revisiting the host city: An empirical examination of sport involvement, place attachment, event satisfaction and spectator intentions at the London Olympics. Tourism Management, 55, 160-172.

[10] Chen, C., Petrick, J., \& Shahvali, M. (2016). Tourism experiences as a stress reliever: Examining the effects of tourism recovery experiences on life satisfaction. Journal of Travel Research,55(2), 150-160. doi:https://doi.org/10.1177/0047287514546223

[11] Cho, H., Joo, D., \& Chi, C. (2019). Examining nostalgia in sport tourism: The case of US college football fans. Tourism Management Perspectives, 29, 97-104. doi:https://doi.org/10.1016/j.tmp.2018.11.002

[12] Cho, H., Lee, H., Moore, D., Norman, W., \& Ramshaw, G. (2017). A multilevel approach to scale development in sport tourist nostalgia. Journal of Travel Research, 56(8), 1094-1106. doi: https:// doi.org/10.1177/0047287516683834

[13] Cox, R.H. (2011) Sport psychology; Concepts and applications ( $7^{\text {th }}$ ed.). McGraw Hill.

[14] Dann, G. M. (1977). Anomie, ego-enhancement and tourism. Annals of Tourism Research, 4(4), $184-194$.

[15] Deci, E. L.,\& Ryan, R. M. (2000). Intrinsic and extrinsic motivations.Contemporary Educational Psychology, 25(1), 54-67.

[16] Deci, E. L.,\&Ryan, R. M. (2002). Handbook of self-determination research. The University of Rochester Press.

[17] Fairley, S. (2003). In search of relived social experience: Group-based nostalgia sport tourism. Journal of Sport Management, 17(3), 284-304. doi:10.1123/jsm.17.3.284

[18] Falls, G., \& Natke, P. (2016). College football attendance: A panel study of the football championship subdivision. Managerial and Decision Economics, 37(8), 530-540. doi:https://doi.org/10.1002/mde.2740

[19] Filep, S., \& Laing, J. (2019). Trends and directions in tourism and positive psychology. Journal of Travel Research, 58(3), 343-354. doi: https://doi.org/10.1177/0047287518759227

[20] Finn, B. (2012). Exploring ski tourist motivations for active sport travel (Publication No. 165).[Master's Thesis, University of Windsor]. Electronic Theses and Dissertations. https://scholar.uwindsor.ca/etd/165 
[21] Floyd, M.F., Gibson, H. Gray. L. P.,\&Thapa, B. (2001). The effect of risk perceptions on intentions to travel in the aftermath of September 11, 2001.Journal of Travel \& Tourism Marketing,15, 2-3.

[22] Flyvbjerg, B. (2006). Five misunderstandings about case-study research. Qualitative Inquiry, 12(2), 219245.

[23] Gengler, C.E.,\&Klenosky, D. B. (1999). Understanding the factors influencing ski destination choice. Journal of Travel and Tourism,59-76.

[24] Getz, D., \& McConnell, A. (2014). Comparing trail runners and mountain bikers: Motivation, involvem ent, portfolios, and event-tourist careers. Null, 15(1), 69-100. doi:10.1080/15470148.2013.834807

[25] Gibbs, G. R. (2007). Analyzing qualitative data: Thematic coding and categorizing. SAGE Publications.

[26] Gibson, H. (1998a). Active sport tourism: Who participates? Leisure Studies, 17(2), 155-170.

[27] Gibson, H. (1998b). Sport tourism: A critical analysis of research. Sport Management Review, 1(1), 45-76.

[28] Gibson, H. (2006). Sport tourism: Concepts and theories. Routledge

[29] Gibson, H. J., Attle, S. P., \& Yiannakis, A. (1998). Segmenting the active sport tourist market: A life-span perspective. Journal of Vacation Marketing, 4(1), 52-64.

[30] Gibson, H., Willming, C., \& Holdnak, A. (2002). "We're Gators ... not just Gator fans": Serious leisure and University of Florida football. Journal of Leisure Research, 34(4), 397-425. doi: https://doi.org/ 10.1080/00222216.2002.11949979

[31] Glyptis, S. (1989). Leisure and unemployment. Open University Press: Milton Keynes, UK.

[32] Gnoth, J. (1997) Tourism motivation and expectation formation: Analysis of Tourism Research, 24(2), 283- 304

[33] Hall, J., O’Mahony, B., \& Gayler, J. (2016). Modelling the relationship between attribute satisfaction, overall satisfaction, and behavioural intentions in Australian ski resorts. Journal of Travel \& Tourism Marketing,34(6), 764-778. doi:10.1080/10548408.2016.1232672

[34] Hall, C. M. \& Weiler, B. (1992). Introduction. What's special about special interest tourism? In: B. Weiler \& C. M. Hall (Eds) Special interest tourism, pp. 1-14. Bellhaven Press.

[35] Hallmann, K., Feiler, S., Müller, S., \& Breuer, C. (2012). The interrelationship between sport activities and the perceived winter sport experience. Journal of Sport \& Tourism, 17(2), 145-163.

[36] Hallmann, K., Zehrer, A., \& Müller, S. (2015). Perceived destination image: An image model for a winter sports destination and its effect on intention to revisit. Journal of Travel Research, 54(1), 94-106.

[37] He, X., \& Luo, J. M. (2020). Relationship among travel motivation, satisfaction and revisit intention of skiers: A case study on the tourists of Urumqi Silk Road Ski Resort. Administrative Sciences, 10(3), 56. doi:10.3390/admsci10030056

[38] Higham, J.E.S.,\&Hinch, T. D. (2000). Sport tourism and the transition to professional rugby union in New Zealand. Reflections on International Tourism: Motivations, Behavior and Tourist Types, 4, 145-158.

[39] Higham, J.E.S.,\&Hinch, T. D. (2002). Sport tourism development: Avenues of tourism development associated with a regional sport franchise at an urban tourism destination. Sport Tourism: Principles and Practice, 19-34.

[40] Higham, J.E.S.,\&Hinch, T. D. (2004). Sport tourism development: Aspects of Tourism. Channel View Publications.

[41] Higham, J.E.S.,\&Hinch T. D. (2011). Sport tourism development. British Library Cataloguing.

[42] Hinch, T. D., \& Higham, J. E. S. (2001). Sport tourism: A framework for research. The International Journal of Tourism Research, 3(1), 45-58.

[43] Hinch, T. D., \& Higham, J. E. S. (2011). Sport tourism development. Channel View Publications.

[44] Hsu, C. H. C.(2010). An extension of the theory of planned behavior model for tourists. Journal of Hospitality \& Tourism Research, 36(3), 390-391.

[45] Hsu, C. H., \& Huang, S. (2010). Formation of tourist behavioral intention and actual behavior. 2010 7th International Conference on Service Systems and Service Management. doi:10.1109/icsssm.2010.5530150

[46] Hudson, S., \& Shephard, G. (1998). Measuring service quality at tourist destinations: An application of importance-performance analysis to an alpine ski resort. Journal of Travel \& Tourism Marketing,7(3), 6177. doi:10.1300/j073v07n03_04

[47] Hudson, S., Ritchie, B., \&Timur, S. (2004). Measuring destination competitiveness: An empirical study of Canadian ski resorts. Tourism Planning and Development, 1(1), 79-94.

[48] IBIS World. (2020). Ski \& snowboard resorts in the US industry trends (2015-2020). Retrieved March 08, 2021, from https://www.ibisworld.com/united-states/market-research-reports/ski-snowboard-resorts-indus try/

[49] IBIS World. (2021). Global biggest industries by revenue in 2021. Retrieved March 08, 2021, from https://www.ibisworld.com/global/industry-trends/biggest-industries-by-revenue-thank-you/ 
[50] Ijspeert, R., \& Hernanadez-Maskivker, G. (2020). Active sport tourists: Millennials vs baby boomers. Journal of Tourism, Heritage \& Services Marketing,6(2), 12-20. doi:10.5281/zenodo.3835813

[51] Jeong, Y., Kim, E., \& Kim, S. (2020). Understanding active sport tourist behaviors in small-scale sports events: Stimulus-organism-response approach. Sustainability, 12(19), 8192. doi:10.3390/su12198192

[52] Kaplanidou, K. (2006). Affective event and destination image: Their influence on Olympic travelers' behavioral intentions. Event Management, 10(2-3), 159-173.

[53] Kaplanidou, K., \& Gibson, H. J. (2010). Predicting behavioral intentions of active event sport tourists: The case of a small-scale recurring sports event. Journal of Sport \& Tourism, 15(2), 163-179.

[54] Keller, P. (2001). Sport and tourism: Introductory report. World Tourism Organization.

[55] Kim, J. H., \& Ritchie, B. W. (2012). Motivation-based typology: An empirical study of golf tourists. Journal of Hospitality \& Tourism Research, 36(2), 251-280.

[56] Klenosky, D. B. (2002). The "pull" of tourism destinations: A means-end investigation. Journal of Travel Research 40(4), 396-403.

[57] Konu, H., Laukkanen, T., \& Komppula, R. (2011). Using ski destination choice criteria to segment Finnish ski resort customers. Tourism Management,32(5), 1096-1105. doi:10.1016/j.tourman.2010.09.010

[58] Kulczycki, C., \& Hyatt, C. (2013). Expanding the conceptualization of nostalgia sport tourism:

[59] Lessons learned from fans left behind after sport franchise relocation. In Heritage, Sport and Tourism (pp. 63-84). Routledge.

[60] Kyle, G., Theodorakis, N., Karageorgiou, A., \& Lafazani, M. (2010). The effect of service quality on customer loyalty within the context of ski resorts. Journal of Park and Recreation Administration,28(1), 115.

[61] Lee, U. I.,\& Pearce, P. L. (2002). Travel motivation and travel career patterns. In Proceedings of First Asia Pacific Forum for Graduate Students Research in Tourism, 22 May, Macao (pp. 17-35). Hong Kong: The Hong Kong Polytechnic University.

[62] Lox, C.L., Martin Ginis, K.A, Gainforth, H.L., \& Petruzzello, S.J. (2020). The psychology of exercise. Routledge.

[63] Lulescu, M. (2020). Motivation and sport: Individual and organisational challenges. Romanian Review of Social Sciences, 10(18), 16-29.

[64] Mansfield, Y., \& Pizam, A. (1999). Consumer behavior in travel and tourism. The Haworth Hospitality Press.

[65] Maslow, A. H. (1943). A theory of human motivation. Psychological Review, 50(4), 370-396.

[66] Maslow, A. H. (1954). Motivation and personality. Harper and Row.

[67] Maslow, A. H. (1962). Toward a psychology of being. D. Van Nostrand Company.

[68] Maslow, A. H. (1970). Motivation and personality. Harper \& Row.

[69] Maslow, A. H. (1987). Motivation and personality (3rd ed.). Pearson Education.

[70] Miles, M. B., \& Huberman, A. M. (1994). Qualitative data analysis: An expanded sourcebook. Sage.

[71] Moreno-Gené, J., Sánchez-Pulido, L., Cristobal-Fransi, E., \& Daries, N. (2018). The economic sustainability of snow tourism: The case of ski resorts in Austria, France, and Italy. Sustainability, 10(9), 3012. doi: https://doi.org/10.3390/su10093012

[72] National Associations of Sports Commissions (2017). Sport tourism: A state of the industry report. Retrieved from https://www.sportscommissions.org/Portals/sportscommissions/Documents/Reports/ST_ report_4_9_17.pdf

[73] Park, J., Kim, M., Nauright, J., \& Kim, Y. (2019). Sport event tourists' (SET’s) behavior: A case study of the PyeongChang Winter Olympics. International Journal of Sports Marketing and Sponsorship, 21(2), 267-284. doi: https://doi.org/10.1108/IJSMS-09-2019-0101

[74] Pearce, P.L. (1982). Perceived changes in holiday destination. Annals of Tourism Research, 9(2), $145-164$.

[75] Pearce, P.L. (1996). Recent research in tourist behavior. Asia Pacific Journal of Tourism Research,1(1), 717.

[76] Prayag, G., Mills, H., Lee, C., \& Soscia, I. (2020). Team identification, discrete emotions, satisfaction, and event attachment: A social identity perspective. Journal of Business Research,112, 373-384. doi: https://doi.org/10.1016/j.jbusres.2019.11.062

[77] Riddington, G., Sinclair, C., \& Milne, N. (2000). Modelling choice and switching behaviour between Scottish ski centres. Applied Economics,32(8), 1011-1018. doi:10.1080/000368400322066

[78] Saldaña, J. (2013). The coding manual for qualitative researchers (2nd ed.). Thousand Oaks, CA: SAGE Publications. 
[79] Serrano-Gómez, V., García-García, Ó., Gambau i Pinasa, V., \& Rial-Boubeta, A. (2020). Characterization of profiles as management strategies based on the importance and valuation that users give to the elements of the golf courses. Sustainability, 12(11), 4781. doi:10.3390/su12114781

[80] Shipway, R., \& Jones, I. (2007). Running away from home: Understanding visitor experiences and behaviour at sport tourism events. International Journal of Tourism Research,9(5), 373-383. doi:10.1002/jtr.641

[81] Skavronskaya, L., Scott, N., Moyle, B., Le, D., Hadinejad, A., Zhang, R., Gardiner, S., Coghlan, A., \&Shakeela, A. (2017). Cognitive psychology and tourism research: State of the art. Tourism Review,72(2), 221-237. doi: https://doi.org/10.1108/TR-03-2017-0041

[82] Smith, A. C., \& Stewart, B. (2007). The travelling fan: Understanding the mechanisms of sport fan consumption in a sport tourism setting. Journal of Sport \& Tourism, 12(3-4), 155-181.

[83] Sports ETA. (2019). National Association of Sports Commissions announces new brand at annual symposium. Retrieved February 05, 2021, from https://www.sportseta.org/blog/2019/05/10/nationalassociation-of-sports-commissions-announces-new-brand-at-annual-symposium

[84] Sports ETA. (2020, September 1). State of the industry report - 2019. Retrieved February 05, 2021, from https://www.sportseta.org/state-of-the-industry-report-2019

[85] Sport Tourism Canada. (2020, May 28). Sport tourism spending in Canada holds steady at $\$ 6.8$ billion. Retrieved March 14, 2021, from https://sporttourismcanada.com/sport-tourism-spending-in-canada-holdssteady-at-6-8-billion/

[86] Standeven, J.,\& DeKnop, P. (1999) Sport tourism. Human Kinetics.

[87] Tjørve, E., Lien, G., \& Flognfeldt, T. (2015). Properties of first-time vs. repeat visitors: Lessons for marketing Norwegian ski resorts. Current Issues in Tourism, 21(1), 78-102. doi:10.1080/13683500. 2015.1062472

[88] U. S. Census. (2020). Regional offices. Retrieved from https://www.census.gov/about/regions.html

[89] Vada, S., Prentice, C., \& Hsiao, A. (2019). The role of positive psychology in tourists' behavioural intentions. Journal of Retailing and Consumer Services, 51, 293-303. doi: https://doi.org/10.101 6/j.jretconser.2019.06.015

[90] Weiner, B (1985). An attribution theory of achievement motivation and emotion.Psychology Review,92(4), 548-573.

[91] William, P.,\&Fidgeon, P. (2000). Addressing participation constraint: A case study of potential skiers. Tourism Management, 21, 379-393.

[92] Won, D., \& Hwang, S. (2009). Factors influencing the college skiers and snowboarders' choice of a ski destination in Korea: A conjoint study. Managing Leisure,14(1), 17-27. doi:10.1080/13606710802551197

[93] Yin, R. K. (2011). Applications of case study research. Sage.

[94] Zinsser, N., Bunker, L., Williams, J.M. (2010). Cognitive techniques for building confidence and enhancing performance. In J.M. Williams (Ed.), Applied Sport Psychology Personal Growth to Peak Performance (pp. 305-335). Human Kinetics.

Citation: Jimmy Smith, et.al. "Exploring Consumer Motivation at Small-Scale Ski Resorts". International Journal of Research in Tourism and Hospitality (IJRTH), vol 7, no. 1, 2021, pp. 16-31. doi: https://doi.org/10.20431/2455-0043.0701003.

Copyright: () 2021 Authors. This is an open-access article distributed under the terms of the Creative Commons Attribution License, which permits unrestricted use, distribution, and reproduction in any medium, provided the original author and source are credited. 